\title{
Epidemiology of fluorosis and dental caries according to different types of water supplies
}

\author{
Epidemiologia da fluorose e cáries dentárias \\ de acordo com diferentes tipos de abastecimento de água
}

Solange de O liveira Braga Franzolin ${ }^{1}$

Aguinaldo Gonçalves ${ }^{2}$

Carlos Roberto Padovani ${ }^{3}$

Leda A parecida Francischone ${ }^{1}$

Sara Nader M arta ${ }^{1}$

${ }^{1}$ Departamento de Ciências daSaúde, Faculdadede Odontologia, Universidade do Sagrado Coração. Rua Irmã Arminda 10-50, Jardim Brasil. 17044-160 Bauru SP. so.franzolin@gmail.com ${ }^{2}$ Departamento de Ciências do Esporte, Faculdadede Educação Física, Universidade Estadual de Campinas.

${ }^{3}$ Departamento de Bioestatística, Faculdade de M edicina, Universidade Estadual Paulista Júlio de M esquita Filho.
Abstract The aim of this article is to investigate the relationship between fluorosis/dental caries in schools, according to the level of fluoride in public water supply. The sample comprised of twelve-year-old daytime students (360) of both genders, attending schoolsclose to theregion where they were born. The schools were classified into three groups according to the presence of fluoride in the water supply: 1) fluoridation in the Water Treatment Station-WTS; 2) Direct Fluoridation in Wells-DFW; and 3) Non Fluoridated AreasNFA. The $\chi^{2}$ and Goodman tests (significance $=5 \%$ ) were used to evaluate the association between the origin of water and degree of fluorosis; percentage of distribution and descriptivemeasures were used for investigation of the degree of fluorosis. The following outcomes were predominant: presence of dental caries in the entire sample $(P<0.05)$; absence of fluorosisin both genders, for white individuals and subjects living in areas supplied by both DFW and NFA $(P<0.05)$. There was no difference in the severity of fluorosis between the sources of water supply $(P>0.05)$. Dental caries is still an important problem in this population, despite the establishment of preventivemeasured. Theobservation of fluorosisin studentsliving in non-fluoridated areas confirms the presence of other sources of fluoride.

Key words Fluorosis, Dental caries, Fluoride, Water supply, Water treatment
Resumo 0 objetivo do presente artigo é investigar a relação fluorose/cáries em escolas, de acordo com o nível de fluoreto no abastecimento público de água. A amostra consistiu em 360 alunos de dozeanos deidade, deambosos sexos, quefrequentam as escolas próximas da região em que nasceram. As escolas foram classificadas em três grupos de acordo com a presença de fluoreto no abastecimento deágua: 1) fluoretação na Estação de Tratamento deÁgua (ETA); 2) fluoretação direta em poços; e 3) áreas não fluoretadas (ANF). O s testes de $\chi^{2}$ e de Goodman (significância $=5 \%$ ) foram utilizados para avaliar a associação entre a origem da água e o grau de fluorose. Os resultados mais predominantes foram presença de cáries em toda a amostra $(P<0,05)$; ausência de fluorose em ambos gêneros, para indivíduos brancos e aqueles vivendo em áreas abastecidas com água fluoretada diretamente de poços e não fluoretadas $(P<0,05)$. $N$ ão houvediferença no grau de severidade da fluorose entre as fontes de abastecimento de água $(P>0,05)$. As cáries ainda são uma importante questão nessa população, apesar do estabel ecimento de medida preventiva. A observação da fluorose em alunos vivendo em áreas não fluoretadas confirma a presença de outras fontes de fluorose. Palavras-chave Fluorose, Cáries dentárias, Fluoreto, Abastecimento de água, Tratamento de água 


\section{Introduction}

Discovery of theanticariogenic properties of fluoride was one of the most important landmarks in the history of Dentistry. During the 1940s and 1950s, the main sources of fluoride were the water supply and food. Since then, other sources have become available, including manufactured beverages and products; fluoridated dental products and medicines such as toothpastes, mouthrinses, gels and solutions for professional application, dietary fluoride supplements, fluoridation of the public drinkable water supplies, and fluoridation of table salt t,2.

Initially, it was believed that the preventive effect of fluoride was related to its incorporation in the dental structure, changing the chemical composition of enamel to increase its resistance to dental caries. After the 1970s, deeper laboratory investigations indicated that fluoride presents a local cariostatic effect, interfering with the $d y$ namic processes (de and remineralization) occurring during the development and progression of the carious lesion. Its presence in low concentrations in the oral cavity is essential for achievement of maximum effect; some authors believe that the widespread utilization of fluoridated toothpastes is one of the important factors for reduction in caries prevalence ${ }^{3}$.

Besides utilization of fluoridated toothpastes, maintenance of a low fluoride concentration in the oral cavity may be achieved by ingestion of fluoridated water - systemic method - in which the fluoride ingested returns to the oral cavity through the saliva and gingival fluid, enhancing remineralization during the period of $\mathrm{pH}$ reduction in the mouth 4 .

In order to provide this benefit to the population of Bauru, São Paulo State, Brazil, fluoridation of the public water supply was initiated in 1975, when sodium fluorosilicate salt was used. Up to August 1981, some interruptions occurred for technical reasons. In 1997, Nagem Filho et al. ${ }^{5}$ showed that the city of Bauru had $88 \%$ of its water fluoridated by the Water and Sewerage Department; $59 \%$ was conducted at the Water Treatment Station (WTS) and $29 \%$ at artesian wells (DFW).

The prolonged use of excessive doses of fluoride during the period of tooth formation causes fluorosis (chronic intoxication by fluoride), showing a linear relation with theprevalenceand severity of enamel alterations in the permanent teeth even at very low doses ( $\mathrm{mgF} / \mathrm{kg}$ ). In dental fluorosis, the affected enamel appears opaque due to the increase in surface porosity and especially in subsurface porosity. The mechanism through which it occurs during amelogenesis has not been elucidated so far, and the susceptibility of teeth should beconsidered. It is clinically characterized by changes ranging from white opaque lines crossing the dental surfaceto loss of external enam$\mathrm{el}$, leading to an altered anatomical shape of the tooth surface. Due to the wide clinical spectrum, some criteria were proposed by authors as Dean and Thylstrup and Fejerskov, known as the D ean index and TF index, respectively, which classify it according to increasing degrees of severity ${ }^{6,7}$.

Banting analyzed the amount of fluoride ingested by children who brushed their teeth with fluoridated toothpastes; the results led the author to recommend the rational use of fluoride, considering therisk of exposureto fluoride from different sources ${ }^{2,8}$.

Epidemiological investigationsin 12-year-old students conducted in different populations demonstrated prevalences of dental fluorosis ranging from 23 to $52.9 \%$, with a very low percentage of moderate/severe grades, in which at most $4 \%$ of cases had esthetic involvement related to the presence of fluorosis?.

This study aimed at verifying the prevalence and associations between fluorosis and dental caries in schoolchildren attending public state schools in Bauru, Brazil, according to the gender and race/color, with regard to the different fluoridation systems of the public water supply practiced by the Water and Sewerage Department of Bauru.

\section{M ethods}

Based on a homogeneous population of 4,570 12-year-old daytime students attending state public schools in Bauru, State of São Paulo, the sample size $^{10}$ was weighed with $10 \%$ of estimate error and 95\% confidencelevel, whose procedure for calculation yielded 354 sample units (students). Theinclusion criteria comprised students living at the same geographical area as the school since birth (students with characteristics of homogeneous population).

Considering the interest to compare three sources of water supply (Water Treatment Station, with regular fluoridation - WTS; Direct Fluoridated in Well, with irregular addition of fluoride - DFW; Non-Fluoridated Areas, well without fluoridation - NFA), the sample size was divided into equal parts, adding up to 118 students per source. 
Four schools of each source were randomly drafted and thesampleunits wereequally designed for theseschools. Thus, each school would have 30 students ( 29.5 rounded to 30 ), sampled by a systematic process, considering the registry number.

The participants presented an informed consent term signed by their parents or caretakers. This study was approved by the Institutional Review Board of University of Sagrado Coração according to Resolution 196/96 of the National $\mathrm{H}$ ealth Council ${ }^{11}$.

The students underwent a clinical examination performed at the school yard under natural light by a singleexaminer ( previously calibrated) hel ped by a recorder, both of whom wereblinded to the type of water supply of that school. Dental mirrors and tongue depressors were used and all biosecurity measures were followed. The epide miological survey was conducted in a singlestage. Examinations for calculation of intra-examiner agreement were performed at onset, middle and completion of the survey on nearly $13 \%$ of the sample. Selection of the group for re-evaluation was performed by the recorder; 50 repetitions were performed for the 360 examinations. Application of the kappa test revealed the following values: $K=0.90$ for the onset, $K=0.92$ for the middle and completion of examinations ${ }^{12}$.

Fluorosis was characterized according to the criteria of the TF index ${ }^{6}$. Parallely, the DM FT index was recorded as initially suggested by Klein and Palmer in 1937 and modified on the manual on "DM F Index" prepared by the Dental H ealth Center in 1965. TheDM FT index of an individual is the total number of teeth with caries experience, including decayed teeth (regardless of the extension or severity of the lesion), filled teeth (dental restorations indicate past caries activity) and teeth extracted due to dental caries ${ }^{13,14}$. Recording of race/color was performed according to the classification of the Brazilian Institute of Geography and Statistics (IBGE), namely White, Black, Admixture, Yellow and Native ${ }^{15}$.

The association between fluorosis and dental caries and the source of water supply was investigated by the non-parametric chi-square $\left(\chi^{2}\right)^{16}$ and Goodman ${ }^{17}$.

\section{Results}

Table 1 demonstrates the frequency of fluorosis and dental caries in schoolchildren according to race/color and gender. From the 360 children examined, 142 presented fluorosis, which corresponds to $39.45 \%$ of the sample. The presence of dental caries in the schoolchildren was approximately six times greater than its absence.

The result of the statistical test related to Table $2(P<0.001)$ revealed that the distribution of students according to fluorosis and dental caries was preferential in thegroup with absence of fluorosis and presence of caries ( 185 students).

Gender was not associated with fluorosis and dental caries, sincein both genders therewas predominance of absence of fluorosis and presence of caries. Also, there was no association between the race/color variable and fluorosis and dental caries; however, there was predominance of absence of fluorosis only among white individuals and a significant presence of caries in all races. Because of the small number of individuals of theyellow race/color ( 3 schoolchildren), this race was combined to the admixture group. Associa-

Table 1. Sample distribution of fluorosis and dental caries according to race/color and gender.

\begin{tabular}{|c|c|c|c|c|c|}
\hline \multirow[b]{2}{*}{ Race/color } & \multirow[b]{2}{*}{ Gender } & \multicolumn{2}{|c|}{ Fluorosis } & \multicolumn{2}{|c|}{ Caries } \\
\hline & & Present & Absent & Present & Absent \\
\hline \multirow[t]{2}{*}{ White } & $M$ & 42 & 79 & 104 & 17 \\
\hline & $\mathrm{F}$ & 48 & 74 & 101 & 21 \\
\hline \multirow[t]{2}{*}{ Black } & $M$ & 7 & 16 & 21 & 2 \\
\hline & $\mathrm{F}$ & 10 & 8 & 18 & 0 \\
\hline \multirow[t]{2}{*}{ Admixture } & $M$ & 20 & 19 & 33 & 6 \\
\hline & $\mathrm{F}$ & 14 & 20 & 28 & 6 \\
\hline \multirow[t]{2}{*}{ Asian } & $M$ & 1 & 1 & 2 & 0 \\
\hline & $\mathrm{F}$ & 0 & 1 & 1 & 0 \\
\hline Total (\%) & & $142(39.45)$ & $218(60.55)$ & 308 (85.55) & $52(14.45)$ \\
\hline
\end{tabular}


tion between the source of public water supply and fluorosis was not statistically significant. However, when each source was independently considered, the absence of fluorosis was predominant for the DFW and NFA sources (Goodman Test). TheDM FT index and source of water supply revealed a lower DM FT for the WTS group $(2.94 \pm 2.29)$ followed by the DFW $(3.82 \pm 3.01)$ and NFA $(4.02 \pm 2.61)$ groups, with coefficient of variation (ratio between standard deviation and mean) of $77.89 \%$; $78.79 \%$; and $64.92 \%$, respectively. With regard to dental caries, therewas predominance of positivity in each source, and presence of caries was more frequent for NFA compared to WTS and DFW (Table 3).

Distribution of thefrequency of degree of fluorosis in relation to the sources of water supply
(WTS, DFW and NFA) is illustrated in Figure 1; no statistically significant differences were observed between the different degrees of fluorosis for the three sources. In all sources, the results indicated a significant decreasing frequency $(P<0.05)$ from the lowest to thehighest degree of fluorosis.

\section{Discussion}

Fluoridation of the public water supply is a health promotion measure recommended by theWorld $\mathrm{H}$ ealth Organization for preservation of dental integrity of the population. In Brazil, the Law $n$. 6050 of M ay $24^{\text {th }} 1974$ makes this procedureobligatory in water treatment services; when regularly
Table 2. Sample distribution and result of the statistical test for the variables fluorosis and dental caries.

\begin{tabular}{llrr}
\hline & & \multicolumn{2}{c}{ Frequency } \\
\cline { 3 - 4 } \multicolumn{1}{c}{ Fluorosis } & Caries & \multicolumn{1}{c}{$\mathrm{f}_{\mathrm{i}}$} & $\mathrm{fr}_{\mathrm{i}}$ \\
\hline Present & Present & 123 & 34.16 \\
Present & Absent & 19 & 5.28 \\
Absent & Present & 185 & 51.39 \\
Absent & Absent & 33 & 9.17 \\
Total & & 360 & 100.0 \\
\hline$(P<0.001)$ & & &
\end{tabular}

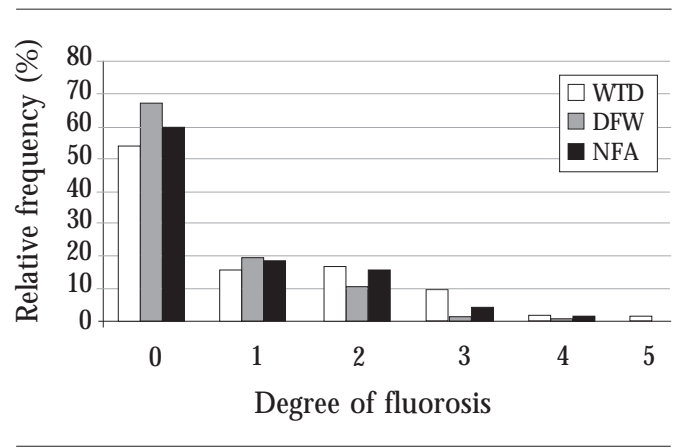

Figure 1. Distribution of the frequency of the different degrees of fluorosis among schoolchildren.

Table 3. Gender - DMFT and related prevalence of fluorosis and dental caries.

\begin{tabular}{|c|c|c|c|c|c|c|}
\hline & \multirow[b]{2}{*}{ DMFT } & \multicolumn{2}{|c|}{ Fluorosis } & \multicolumn{2}{|c|}{ Caries } & \multirow[b]{2}{*}{ Total } \\
\hline & & Present & Absent & Present & Absent & \\
\hline \multicolumn{7}{|l|}{ Gender } \\
\hline Male & 3.44 & 70 (37.84) & $115(62,16)^{*}$ & $160(86.49)^{*}$ & $25(13.51)$ & 185 \\
\hline Female & 3.75 & 72 (41.14) & $103(58.86)^{*}$ & $148(84.57)^{*}$ & $27(15.43)$ & 175 \\
\hline \multicolumn{7}{|l|}{ Race/color } \\
\hline White & 3.42 & 90 (37.04) & $153(62.96)^{*}$ & $205(84.36)^{*}$ & 38 (15.64) & 243 \\
\hline Black & 3.68 & 17 (41.46) & $24(58.54)$ & $39(95.12) *$ & $2(4.88)$ & 41 \\
\hline Admixture & 4.09 & 35 (46.05) & $41(53.95)$ & $64(84.21)^{*}$ & $12(15.79)$ & 76 \\
\hline \multicolumn{7}{|l|}{ Source } \\
\hline WTS & $2.94 \pm 2.29$ & 55 (45.84) & $65(54.16)$ & $96(80.00)^{*}$ & $24(20.00)$ & 120 \\
\hline DFW & $3.82 \pm 3.01$ & $39(32.50)$ & $81(67.50)^{*}$ & $104(86.67)^{*}$ & 16 (13.33) & 120 \\
\hline NFA & $4,02 \pm 2.61$ & $48(40.00)$ & $72(60.00) *$ & $110(91.67)^{* \#}$ & $10(8.33)$ & 120 \\
\hline
\end{tabular}

*Present vs Absent $(\mathrm{P}<0.05)$; ${ }^{*}$ Comparison between source (WTS; DFW; NFA) $(\mathrm{P}<0.05)$. 
performed, it allows up to $60 \%$ reduction in dental caries ${ }^{1,4}$. The literature shows a reduction in the prevalence of caries at 12 years of age in several countries, certainly due to the increased exposure to fluoride through its various forms of application, especially by the water supply and utilization of fluoridated toothpastes ${ }^{18}$.

Concomitantly to thereduction in cariesprevalence, there has been an increase in dental fluorosis, even in non-fluoridated areas. Murray and Buzalaf et al. identified some risk factors to fluorosis, as excessive use of supplements, utilization of manufactured baby foods, gels and mouthwashes, excessive use of tooth pastes ${ }^{1,2}$. All these products contain fluoride in their composition. Pendrys estimated athree fold increase in therisk to fluorosis among 12- to 16-year-old children in fluoridated areas, especially due to the utilization of fluoridated toothpastes (75\%) and fluoride supplements $(25 \%)^{19}$.

Thus, the issue of "fluorosis" led to the development of several studies, and the ideal fluoride dosage currently recommended is related to the child's weight instead of the age ${ }^{20}$.

Adequateand safe fluoride dosages have been discussed, and authors as Banting have advised that this dosage is easily 2 to 3.5 times higher than recommended in areas supplied with optimally fluoridated water combined to other sources like toothpastes, mouthrinses, beverages and food $^{8}$. M oreover, special attention should begiven to children under 5 years of age who ingest an average of $0.5 \mathrm{~g}$ of toothpaste during toothbrushing, suppressing the fluoride tolerance threshold ${ }^{21}$. The presence of fluorosisin children of the NFA group (Table 3) agrees with these studies, since the appearance of fluorotic teeth in this group was probably due to means other than the public water supply, which was not fluoridated. This proves that the presence of fluorosis did not depend on the type of water supply.

There is evidenceabout theincreasein dental fluorosis due to the increase in fluoride ingestion, especially through fluoridated toothpastes. TheUnited States Public Health Service estimates this to be $5 \%$ for fluoridated areas and $9 \%$ in the non-fluoridated ${ }^{22}$.

The longitudinal study of children from birth to nine months old conducted by Levy et al. showed that ingestion of fluoride through water, supplements and toothpaste greatly contributed to the proportion of fluoride ingested beyond the "optimum" recommended level ${ }^{23}$. However, there is the need to assess the condition of the child in order to prescribe these supplements, consider- ing the risk to dental caries; knowledge of parents and the child's behavior toward prevention; the child's physical and mental development; intake of medicines; and exposure to fluoride.

Furthermore, due to the difficulty to quantify the fluoride ingestion in food and beverages, it is important to limit its consumption from other sources; utilization of fluoridated toothpaste by preschool children should be supervised by their parents, monitoring the amount used and rinsing after brushing; the fluoride concentration in these products should be reduced.

The study conducted by Lima and Cury, in 2000, corroborated these results and showed that therelativecontribution from diet in children aged five years old was $46 \%$ compared to $54 \%$ from toothpastes for the total dose of ingested fluoride; thestudy used fluoridated water $(0.62 \mathrm{ppm})$ combined with food (prepared with the same water) and fluoridated toothpaste (1,100 ppm). Considering that $0.07 \mathrm{mg} / \mathrm{F}$ per $\mathrm{Kg}$ is the limit dose for clinically acceptable fluorosis, children might be subjected to a risk dose by fluoride ingestion through diet and through toothpaste ${ }^{24}$.

In summary, it is very important to assess the benefits of fluoride as a method for caries prevention; however, the risk to fluorosis should al so beconsidered, since its availability from several sources might easily lead to doses above the recommended levels, contributing to an increase in the prevalence of fluorosis.

Besides presence, another important factor that should be investigated is the severity of the disease, represented by distribution of the degrees of fluorosis (Figure 1), which in the present study was similar for the three sources investigated with predominance of milder degrees; this confirms the results of previous studies, as those presented by Moysés and M oysés?.

The clinical characterization of fluorosis is well established ${ }^{6}$, yet the mechanism underlying its occurrence has not been totally explained; not only the amount of ingested fluoride should be considered, but also the susceptibility of teeth? The possibility of influence from the variables race/color and gender on the development of fluorosis was analyzed and no relationship was found with theoccurrence of either fluorosis ( $\mathrm{Ta}$ ble 1) or dental caries (Tables 3).

Although fluoridation of the public water supply may reduce the caries prevalence in up to $60 \%{ }^{1,3,4}$, this method presented to be insufficient to prevent the appearance of the disease, since $85 \%$ of children had at least one carious lesion (Table 2). 
Analysis of the caries prevalence in the study population revealed that the DMFT values favored theWTSgroup, with DM FT $=2.94 \pm 2.29$, closely followed by the other groups, namely DFW $=3.82 \pm 3.01$ and NFA $=4.02 \pm 2.61$ (Table 3). The former was the only group (WTS) within the values recommended by the WHO for the year $2000^{25}$. This could be associated with the effectivecontrol of fluoridation in this source, as confirmed by the analyses of Nagem et al. ${ }^{5}$ and Tavares and Bastos $^{26}$, which found optimum levels of fluoride in Bauru for the water from this station (from 0.6 to $0.8 \mathrm{ppm}$ ), which assured the protective properties of fluoride, sincethefluoridation in the DFW source is irregular. This may be demonstrated by the coefficient of variation of DM FT, which was more homogeneous for the NFA group, with lower ratio between coefficient of variation and DMFT (64.92\%), followed by WTF $(77.89 \%)$ and DFW (78.79\%), as confirmed by analysis of the presence of caries between sources, which reveal ed a statistically significant difference between WTF and NFA (Table 3).

H owever, epidemiological surveys conducted in Bauru showed that the DM FT was reduced since 1975 despite the discontinued fluoridation of public water supply, with values of $3.97^{27}, 4.87^{28}$ and 3.57 for this study sample (Table 3) at 12 years old; this is probably due to the association of alternative methods combined to fluoridation of the public water supply, such as utilization of fluoridated toothpastes ${ }^{29}$.

\section{Conclusions}

The number of schoolchildren presenting caries was al ways higher when compared to those without the disease, regardless of the gender, race and source of water supply.

The DM FT index for the 360 schoolchildren examined was higher for the female gender, admixture group and NFA.

The finding of cases of fluorosis among schoolchildren from the NFA group confirms the existence of fluoride sources other than water for this population, since this water was not fluoridated.

The absence of fluorosis was predominant in groups receiving fluoridated water from the DFW and NFA.

Only the schoolchildren in the WTS group presented a DMFT index below 3, probably because of the better water fluoridation, demonstrating the efficacy of this method; thus, this preventive measure should be recommended for our population.

For all three areas, namely WTS, DFW and NFA, there was predominance of the mildest degrees of fluorosis (TF grades 1, 2 and 3), which did not bring about severe esthetic involvement.

\section{Collaborators}

SOB Franzolin, A Gonçalves, CR Padovani, LA Francischo and SN M arta have equally participated in all stages of theelaboration of thearticle. 


\section{References}

1. Murray JJ. Appropriate use of fluorides for human health. Geneva: World Health Organization; 1986.

2. Buzalaf MAR, Damante CA, Trevizane LMM Granjeiro JM. Risc of fluorosis associated with infant formulas prepared with bottled water. J Dent Child. 2004; 71:110-113.

3. Thylstrup A. Clinical evidence of the role of preeruptive fluoride in caries prevention. J Dent Res. 1990; 69(Spec Iss):742-750.

4. Cury JA. U so do flúor e controle da cárie como doença. In: Baratieri LN, organizador. Odontologia restauradora - fundamentos e possibilidades. São PauIo: Santos; 2001. p. 33-68.

5. Nagem Filho $H, M$ aria VS, Aragão HDN, Leirião JÁ, Sato S, Sitanaka MH, Garcia MZ, Galhardo E. Determinação da taxa de flúor da água de abastecimento da cidade de Bauru. Bauru: EDUSC; 1997.

6. Fegerskov O, Manji F, Baelum V, Møller I J. Dental fluorosis. A handbook for health workers. Copenhagen: M unksgaard International Publishe; 1988.

7. DenBesten PK. Biological mechanisms of dental fluorosis relevant to the use of fluoride supplements. Community Dent Oral Epidemiol. 1999; 27:41-47.

8. Banting DW. International fluoride supplement recommendations. Community Dent Oral Epidemiol. 1999; 27:57-61.

9. Moysés ST, M oysés SJ. Fluorose dentária. In: Antunes JLF, Peres MA, organizadores. Epidemiologia da saúde bucal. 54a ed. Rio de Janeiro: Guanabara Koogan; 2006. p. 115-127.

10. Cochran W. Sampling techniques. New York: John Wiley; 1977.

11. Brasil. Ministério da Saúde. Conselho Nacional de Saúde. Resolução nº 196, de 10 de outubro de 1996. Regulamenta pesquisa envolvendo seres humanos. Diário Oficial da União 1996; 16 out.

12. Pereira M G. Epidemiologia teoria e prática. Rio de Janeiro: Guanabara Koogan; 1999.

13. Klein $\mathrm{H}$, Palmer C E. Dental caries in american indian children. In: Chaves M M , organizador. Odontologia social. Rio de Janeiro: Artes M édicas; 1986. p. 83-98.

14. Dental Health Center. The DM FT: Index. San Francisco: Dental Health Center; 1965. [M imeo]

15. Instituto Brasileiro de Geografia e Estatística. Pesquisa Nacional por Amostra de Domicílios. Rio de Janeiro: IBGE; 1997.

16. Johnson A, Wichern DW. Applied multivasiate statistical analyses. New Jersey: Prendice Hall International Inc; 1992.

17. Goodman LA. On simultaneous confidence intervals for multinomial proportions. Technometrics 1965; 7:247-254.
18. Weyne SC. A construção do paradigma de promoção de saúde - um desafio para as novas gerações. In: Kriger L, organizador. ABOPREV: promoção de saúde bucal. São Paulo: Artes M édicas; 1999. p. 1-26.

19. Pendrys DG. Risk of fluorosis in a fluoridated population: Implication for the Dentist and Hygienist. J Amer Dent Ass. 1995; 126:1617-1624.

20. N ewbrum E. Current regulations and recommendations concerning water fluoridation, fluoride supplements and topical fluoride agents. J Dent Res. 1992; 71:1255-1265.

21. Simard PL, Lachapelle D, Thahan L, Naccache H, Demers M, Brodeur JM. The investigation of fluoride dentifrice by young children. J Dent Child. 1989; 58:177-181.

22. Griffin SO, Beltrán ED, Lockwood SA, Barker LK. Esthetically objectionable fluorosis attributable to water fluoridation. Community Dent Oral Epidemiol. 2002; 30:199-209.

23. Levy SM, Kohout FJ, Kiritsy M C, Heilman JR, Wefel JS. Infants' fluoride ingestion from water, suplements and dentifrice. J Amer Dent Ass. 1995; 126:1625-1632.

24. Lima YBO, Cury JA. Ingestão de flúor por crianças pela água e dentifrícios. Rev. Saude Publica 2001; 35: 576-581.

25. International Dental Federation. Goals for oral health in the year 2000. Brit Dent J. 1982; 152:21-23.

26. Tavares PC, Bastos JRM. Concentração de flúor na água: cárie, fluorose e teor de flúor urinário em escolares de Bauru, SP. Rev Ass Paul Cirurg. Dent. 1999; 53:407-418.

27. Barros ERC; Tovo M F; Scapini C. Análise crítica da fluoretação de águas. Rev Gaúcha O dont. 1990; 38:247-254.

28. Poletto LTA. Levantamento epidemiológico do estado de saúde bucal da população urbana na cidade de Bauru [tese]. Bauru (SP): Faculdade de Odontologia de Bauru da USP; 1993.

29. Rando-M eirelles M PM, Hoffmann RHS, Silva DD, Sousa MLR. Fluorose dentária em pré-escolares e escolares de municípios com e sem água fluoretada na região de Sorocaba, SP, Brasil. Cienc O dontol Bras 2008; 11:84-90.

Artigo apresentado em 19/05/2008

Aprovado em 04/09/2008

Versão final apresentada em 29/10/2008 